\title{
Chromosome 19p13.3 deletion in a child with Peutz-Jeghers syndrome, congenital heart defect, high myopia, learning difficulties and dysmorphic features: Clinical and molecular characterization of a new contiguous gene syndrome
}

\author{
Josiane Souza $^{1}$, Fábio Faucz ${ }^{1}$, Vanessa Sotomaior ${ }^{1}$, Aguinaldo Bonalumi Filho ${ }^{1}$, Jill Rosenfeld ${ }^{2}$ \\ and Salmo Raskin ${ }^{1,3}$ \\ ${ }^{I}$ Núcleo de Investigação Molecular Avançada, Programa de Pós-Graduação em Ciências da Saúde, \\ Centro de Ciencias Biológicas e da Saúde, Pontificia Universidade Catolica do Paraná, Curitiba, \\ PR, Brazil. \\ ${ }^{2}$ Signature Genomics, Spokane, Washington, USA. \\ ${ }^{3}$ GENETIKA - Centro de Aconselhamento e Laboratorio de Genetica, Curitiba, PR, Brazil.
}

\begin{abstract}
The Peutz-Jeghers syndrome (PJS) is an autosomal-dominant hamartomatous polyposis syndrome characterized by mucocutaneous pigmentation, gastrointestinal polyps and the increased risk of multiple cancers. The causative point mutation in the STK11 gene of most patients accounts for about $30 \%$ of the cases of partial and complete gene deletion. This is a report on a girl with PJS features, learning difficulties, dysmorphic features and cardiac malformation, bearing a de novo $1.1 \mathrm{Mb}$ deletion at 19p13.3. This deletion encompasses at least 47 genes, including STK11. This is the first report on 19p13.3 deletion associated with a PJS phenotype, as well as other atypical manifestations, thereby implying a new contiguous gene syndrome.
\end{abstract}

Key words: 19p13.3 deletion, comparative genomic hybridization array, contiguous gene syndrome,

Peutz-Jeghers syndrome, STK11 gene.

Received: April 15, 2011; Accepted: July 14, 2011.

The Peutz-Jeghers syndrome (PJS) is a rare autosomal-dominant disease characterized by gastrointestinal polyposis and mucocutaneous pigmentation. It is associated with a predisposition for various types of benign and malignant gastrointestinal and extra-intestinal tumors (Giardiello and Trimbath, 2006). In 1998, point mutations in the STK11(LKB1) gene were described as inducing PJS (Hemminki et al., 1998; Jenne et al., 1998). STK11, mapped at $19 \mathrm{p} 13.3$, encodes a serine-threonine protein kinase that acts as a regulator of cell-cycle metabolism and cell polarity, with evidence of tumor suppressor functions (Forcet et al., 2005).

Germline point mutations in STK11 have been identified in most patients with PJS, with partial or whole gene deletion in approximately $30 \%$ of these (Aretz et al., 2005; Resta et al., 2010). Some PJS individuals with deletions of up to $250 \mathrm{~kb}$, encompassing STK11 and neighboring genes, have been described (Le Meur et al., 2004; Resta et al., 2010). Only one patient with a large deletion, between

Send correspondence to Salmo Raskin. GENETIKA - Centro de Aconselhamento e Laboratorio de Genetica, Rua Saldanha Marinho 1782, Bairro Bigorrilho, 80730-180 Curitiba, PR, Brazil. E-mail: genetika@genetika.com.br.
220-250 kb, presented other features in addition to PJS characteristics, namely learning disability and scoliosis (Le Meur et al., 2004). Carriers of larger deletions at 19p13.3, but without PJS features, have been reported (Archer et al., 2005; Hurgoiu and Suciu, 1984). Here, a patient with PJS, as well as other atypical clinical manifestations due to a $\sim 1.1 \mathrm{Mb}$ deletion at $19 \mathrm{p} 13.3$, is described.

The patient, a girl, was the second child of a non-consanguineous and healthy couple. The father was 30 -yearsold, and the mother 28 , at the time of birth. The first child, an apparently normal boy at birth, was stillborn after a complicated delivery. The girl was delivered at term, by caesarean section, after an uncomplicated pregnancy. Birth weight was $2500 \mathrm{~g}$, body length $44 \mathrm{~cm}$, and Apgar scores 3 and 5. For the first 18 days, she required intensive care-unit intervention with supplemental oxygen. At five days of age, atrial and ventricular septal defects were diagnosed, which were surgically corrected at 10 months. Hypotonia was noted in the first year of life. She had a seizure at five years-old, without recurrence. She started walking at age five, when she also developed diurnal sphincter control. The onset of menarche occurred at 13, followed by normal menstrual periods. At 14, learning disability was apparent, 
together with the absence of nocturnal sphincter control. Her height was $153.5 \mathrm{~cm}\left(10^{\text {th }}\right.$ centile $)$, weight $48.5 \mathrm{~kg}\left(10^{\text {th }}\right.$ centile) and head circumference $54 \mathrm{~cm}\left(50^{\text {th }}\right.$ centile). High myopia of -13 diopters affected both eyes. Dysmorphic features included epicanthic folds, high nasal bridge, mild kyphoscoliosis, cubitus valgus and a wide gap between the 1 st and 2nd toes. Black pigment spots were noted on the eyelids, nose, cheeks and lips (Figure 1).

At 14 years-old, medical evaluation included normal karyotype, renal ultrasound, magnetic resonance-imaging of the brain, electroencephalogram and electroneuromyography and colonoscopy. Vertebral column radiography documented mild kyphoscoliosis and hyperlordosis. Polysomnography revealed 63 apneic episodes.

Microarray-based comparative genomic hybridization (array CGH) was initially carried out with DNA extracted from the peripheral blood of the patient and her parents, using a bacterial artificial chromosome (BAC) microarray (the SignatureChip Whole Genome; Signature Genomic Laboratories, Spokane, WA), as previously described (Ballif et al., 2008). The extent of deletion in the patient was more precisely defined using a $135 \mathrm{~K}$-feature oligonucleotide-based microarray (SignatureChip Oligo SolutionTM, version 2.0, designed by Signature Genomics and manufactured by Roche Nimblegen, Madison, WI), according to previously described methods (Duker et al.,
2010). Fluorescence in situ hybridization (FISH) was with metaphase cells from the patient and her parents, using BAC clone CTD-2589F14 from 19p13.3, according to Traylor et al. (2009). Interphase FISH using BAC clone CTD-2086M18 from 3q29 was also carried out on the patient, according to Ballif et al. (2008).

Oligonucleotide-based array $\mathrm{CGH}$ revealed an approximately $1.1 \mathrm{Mb}$ deletion at 19p13.3 (chr19:213,080$1,322,552$, UCSC hg 18 in the patient). Normal FISH and BAC-based array results in her parents pointed to this deletion as being de novo. Furthermore, the patient also presented $760 \mathrm{~kb}$ duplication at 3q29 (chr3:197,254,006-198,014,826). As BAC-based microarray analysis of the parents showed the mother as carrying this same duplication, this was considered as maternal in origin.

The $\sim 1.1 \mathrm{Mb}$ deletion in our patient encompassed at least 47 genes: PPAP2C, MIER2, THEG, C2CD4C, SHC2 ODF3L2,, MADCAM1, C19orf20, CDC34, GZMM, BSG, HCN2, POLRMT, FGF22, FSTL3, RNF126, PRSSL1, PALM, C19orf21, PTBP1, LPPR3, AZU1, PRTN3, ELANE, CFD, MED16, C19orf22, KISS1R, ARID3A, WDR18, GRIN3B, C19orf6, CNN2, ABCA7, HMHA1, POLR2E, GPX4, SBNO2, STK11, C19orf26, ATP5D, MIDN, C19orf23, CIRBP, C19orf24, EFNA2, and MUM1 (Figure 2).

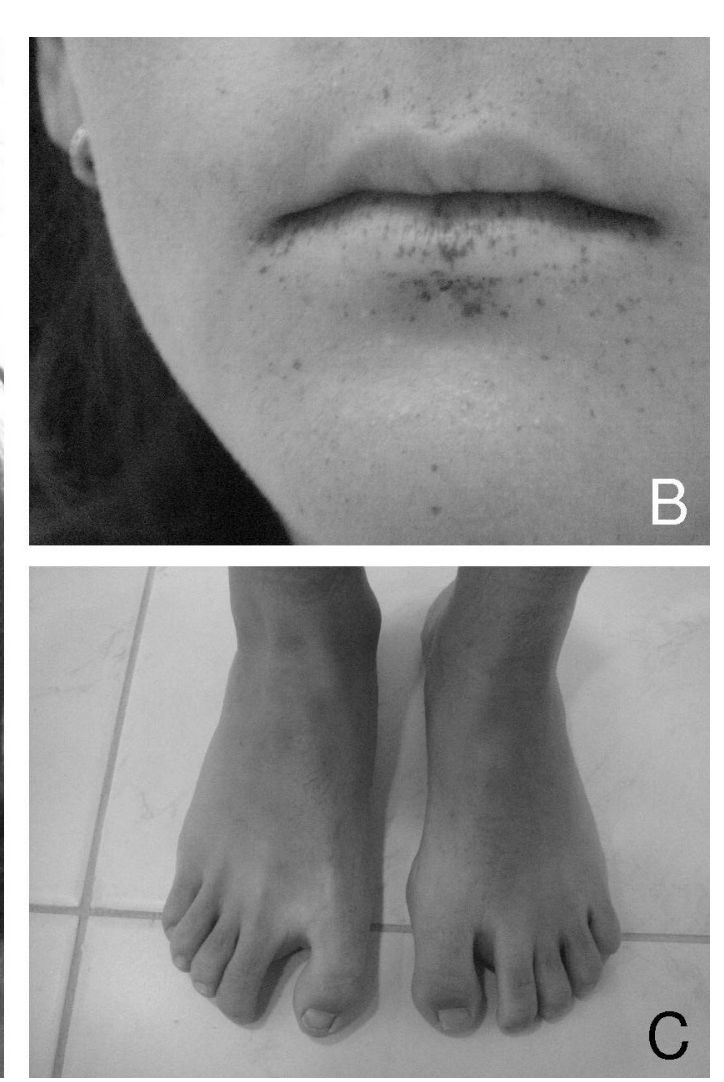

Figure 1 - Patient at 14 years of age. A and B - Facial appearance. Note the epicanthic folds, high nasal bridge and black pigment spots on the eyelids, nose, cheeks and lips. C - Note the wide gap between the first and second toes. 


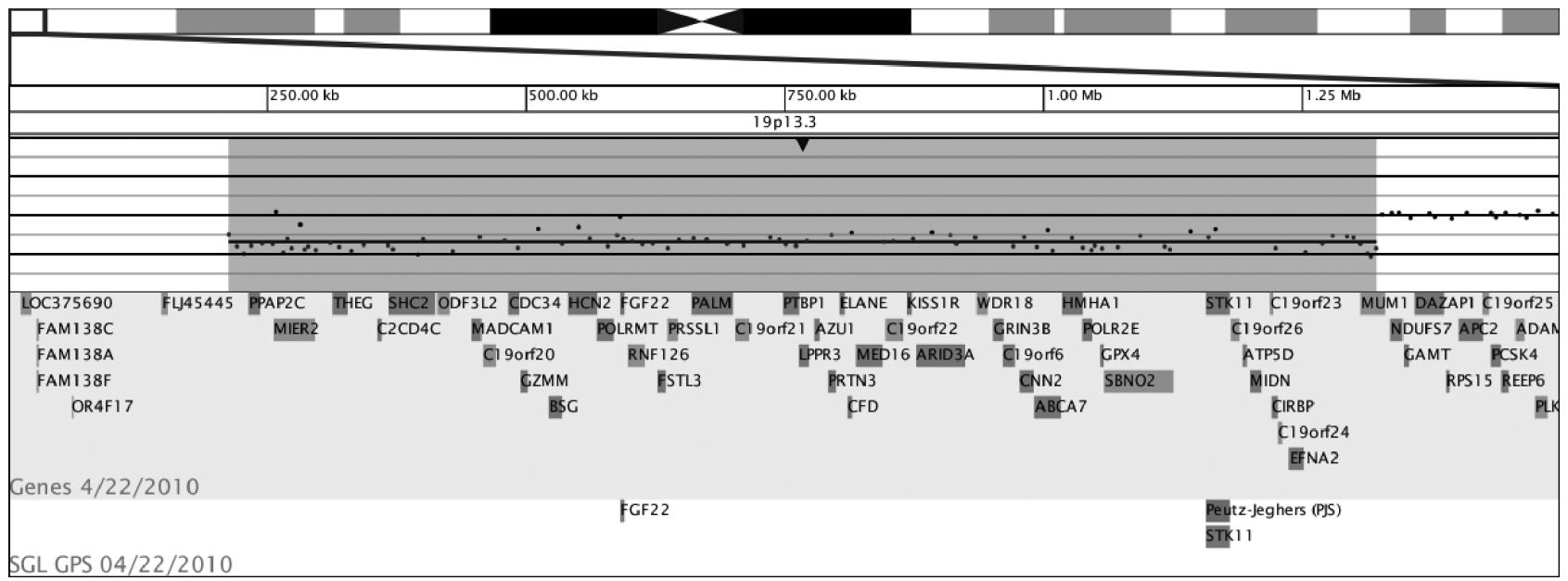

Figure 2 - Deletion at 19p13.3. Array-CGH analysis showed a single-copy loss of 84 oligonucleotide probes at 19p13.3, approximately $1.1 \mathrm{Mb}$ in size (chr19:213,080-1,322,552, UCSC March 2006 hg18 assembly). Genes encompassed by the deletion are listed.

The girl, although here described as the third patient reported with a larger than $1 \mathrm{Mb}$ deletion at $19 \mathrm{p} 13.3$, is the first presenting a PJS phenotype and other atypical clinical manifestations in association with this deletion. The twomonths-old patient reported by Hurgoiu and Suciu (1984), presented, through ocular findings, primitive vitreous body and punched-out lesions of the retina. Besides being deaf, spastic, microcephalic and anemic, there were epicanthic folds and umbilical hernia. By karyotyping, his deletion was defined as 19p13-pter, with no further molecular characterization, thus thwarting a clear comparison with the deletion in our patient.

The male patient described by Archer et al. (2005) presented unusual facial appearance, cleft palate, mixed sensorineural and conductive deafness, a congenital heart defect, keloid scaring, immune dysfunction, seizures and moderate learning difficulties. His $\sim 1.2 \mathrm{Mb}$ deletion involved approximately 60 genes. After FISH, a BAC clone containing STK11 gene was found to be partially deleted, thus impeding gene-status definition. Features shared with our patient were a congenital heart defect and learning difficulties. The aforementioned congenital heart defect was characterized by pulmonary stenosis with dysplastic tricuspid valve, a ventricular septal defect (VSD) and mild over-ride of the aorta. Two of his five siblings, although without the 19p13.3 deletion, also bore congenital heart defects, as coarctation of the aorta, bicuspid aortic valve and a VSD in one, and an atrioseptal defect in the other. Notwithstanding, the authors suggested that the cardiac defect in their patient was more likely related to deletion of the 19 p13.3 chromosome, than to a family-trait.

Some of the genes mapped to the deleted segment, both in our patient and that of Archer et al. (2005), might be related to cardiac anomalies. $C N N 2$ (calponin 2) codes for a protein that is involved in smooth-muscle contraction. Shown to be expressed in mouse embryonic and adult hearts (Masuda et al., 1996), it appears to be co-localized with vinculin in the cell-to-cell junctions of cardiomyocytes. SHC2 (SHC transforming protein 2), besides encoding a member of the SHC family of cell signaling proteins, interacts with the vascular endothelial growth factor (VEGF) (Ratcliffe et al., 2002). The VEGF signaling system plays a critical role in heart formation (Vannay et al., 2006; Zhao et al, 2010). FSTL3 (follistatin like 3), a developmental gene coding for a member of the follistatinmodule protein family, is composed of extracellular matrix-associated glycoproteins. It acts by binding morphogenesis or growth and differentiation factors, as well as regulating their activity during development (Arai et al., 2003). FSTL, abundantly expressed in fetal and adult mouse hearts, neutralizes several transforming growth factor-beta (TGF-beta) superfamily members, this including myostatin (Takehara-Kasamatsu et al., 2007). FSTL3 also binds both activin and BMP2 (Tsuchida et al., 2000). A hypomorphic BMP2 (bone morphogenetic protein 2) receptor has been associated with congenital heart defects in murine models (Delot et al., 2003). Recently BMP2induced kinase was associated with the high level myopia (Liu et al., 2009) present in our patient. Therefore, haploinsufficiency of FSTL3 may contribute to both heart defects and ocular anomalies.

Another gene, possibly related to cardiac malformation, is PTBPI (polypyrimidine tract binding protein 1). This belongs to a subfamily of ubiquitously expressed heterogeneous nuclear ribonucleoproteins, RNA-binding proteins that appear to influence mRNA processing. Zhang et al. (2009) showed that PTB, besides contributing to apoptotic gene expression, also modulates susceptibility to caspase activation by differentiating rat cardiomyocytes. Cardiac morphologic abnormalities were also found in mice deficient in key regulators of caspase-dependent signaling.

The DatabasE of Chromosomal Imbalance and Phenotype in Humans using Ensemble Resources 
(DECIPHER) lists large 19p13.3 deletion cases. Phenotypes were not reported in a patient with an $0.72 \mathrm{Mb} d e$ novo deletion and another with an $0.89 \mathrm{Mb}$, whose parents had not been analyzed. Another patient with an atrial septum defect and intellectual disability, besides bearing an $0.58 \mathrm{Mb}$ deletion at $19 \mathrm{p} 13.3$ which did not encompass STK11, also carried $2 \mathrm{Mb}$ duplication at 16q24. Parents had also not been analyzed.

Le Meur et al. (2004) reported a PJS patient with learning disabilities, scoliosis and paternally inherited type 1 neurofibromatosis (NF1). His $250 \mathrm{~kb}$ deletion at 19p13.3, including STK11, was inherited from his mother, also diagnosed as PJS. The concomitant presence of NF1 makes it difficult to attribute learning disability to $19 \mathrm{p} 13.3$ deletion. This deletion also removed GRIN3B, CNN2, ABCA7, HMHA1, POLR2E, GPX4 and SBNO2 genes.

The PJS features in our patient can be attributed to haploinsufficiency for STK11. STK11 haploinsufficiency could not be proved in the patient with a deletion at 19p13.3, but without PJS features, as reported by Archer et al. (2005). Whereas, it was proposed that this patient might have a milder and undiagnosed disease or that haploinsufficiency for STK11 might not cause PJS, in the very same year, Aretz et al. (2005) reported that approximately $30 \%$ of the patients with PJS presented partial or complete STK11 deletion, and STK11 haploinsufficiency was confirmed as a cause for PJS in other patients (Hearle et al., 2006; Resta et al., 2010; Volikos et al., 2006).

Resta et al. (2010), on evaluating 51 patients with PJS, found 15 STK11 deletions ranging from 2.9 to $180 \mathrm{~kb}$, six of which including additional genes. As these patients presented classical PJS features, but no further anomalies, they proposed that haploinsufficiency of the contiguous genes SBNO2, C19orf26, ATP5D, MIDN, C19orf23, CIRBP, C19orf24 and EFNA2 did not impact the phenotype. These genes, also deleted in our patient, should not be considered as candidates for her atypical clinical features.

In addition to the $19 \mathrm{p} 13.3$ deletion, our patient showed a maternally inherited $760 \mathrm{~kb}$ duplication at 3q29, encompassing 10 genes. Most probably it is a copy number variation without overt clinical impact, as this was also present in her phenotypically normal mother.

In conclusion we describe a patient with PJS and other clinical findings associated with a deletion at 19p13.3. This case illustrates the need of screening for large deletions those patients who present PJS together with atypical clinical features.

\section{References}

Arai KY, Tsuchida K, Uehara K, Taya K and Sugino H (2003) Characterization of rat follistatin-related gene: Effects of estrous cycle stage and pregnancy on its messenger RNA expression in rat reproductive tissues. Biol Reprod 68:199206.
Archer HL, Gupta S, Enoch S, Thompson P, Rowbottom A, Chua I, Warren S, Johnson D, Ledbetter DH, Lese-Martin C, et al. (2005) Distinct phenotype associated with a cryptic subtelomeric deletion of 19p13.3-pter. Am J Med Genet A 136:38-44.

Aretz S, Stienen D, Uhlhaas S, Loff S, Back W, Pagenstecher C, McLeod DR, Graham GE, Mangold E, Santer R, et al. (2005) High proportion of large genomic STK11 deletions in Peutz-Jeghers syndrome. Hum Mutat 26:513-519.

Ballif BC, Theisen A, Coppinger J, Gowans GC, Hersh JH, Madan-Khetarpal S, Schmidt KR, Tervo R, Escobar LF, Friedrich CA, et al. (2008) Expanding the clinical phenotype of the 3q29 microdeletion syndrome and characterization of the reciprocal microduplication. Mol Cytogenet 1:e8.

Delot EC, Bahamonde ME, Zhao M and Lyons KM (2003) BMP signaling is required for septation of the outflow tract of the mammalian heart. Development 130:209-220.

Duker AL, Ballif BC, Bawle EV, Person RE, Mahadevan S, Alliman S, Thompson R, Traylor R, Bejjani BA, Shaffer LG, et al. (2010) Paternally inherited microdeletion at 15 q11.2 confirms a significant role for the SNORD116 C/D box snoRNA cluster in Prader-Willi syndrome. Eur J Hum Genet 18:1196-1201.

Forcet C, Etienne-Manneville S, Gaude H, Fournier L, Debilly S, Salmi M, Baas A, Olschwang S, Clevers H and Billaud M (2005) Functional analysis of Peutz-Jeghers mutations reveals that the LKB1 C-terminal region exerts a crucial role in regulating both the AMPK pathway and the cell polarity. Hum Mol Genet 14:1283-1292.

Giardiello FM and Trimbath JD (2006) Peutz-Jeghers syndrome and management recommendations. Clin Gastroenterol Hepatol 4:408-415.

Hearle NC, Rudd MF, Lim W, Murday V, Lim AG, Phillips RK, Lee PW, O'Donohue J, Morrison PJ, Norman A, et al. (2006) Exonic STK11 deletions are not a rare cause of Peutz-Jeghers syndrome. J Med Genet 43:e15.

Hemminki A, Markie D, Tomlinson I, Avizienyte E, Roth S, Loukola A, Bignell G, Warren W, Aminoff M, Hoglund P, et al. (1998) A serine/threonine kinase gene defective in Peutz-Jeghers syndrome. Nature 391:184-187.

Hurgoiu V and Suciu S (1984) Occurrence of 19p- in an infant with multiple dysmorphic features. Ann Genet 27:56-57.

Jenne DE, Reimann H, Nezu J, Friedel W, Loff S, Jeschke R, Muller O, Back W and Zimmer M (1998) Peutz-Jeghers syndrome is caused by mutations in a novel serine threonine kinase. Nat Genet 18:38-43.

Le Meur N, Martin C, Saugier-Veber P, Joly G, Lemoine F, Moirot H, Rossi A, Bachy B, Cabot A, Joly P, et al. (2004) Complete germline deletion of the STK11 gene in a family with Peutz-Jeghers syndrome. Eur J Hum Genet 12:415418.

Liu HP, Lin YJ, Lin WY, Wan L, Sheu JJ, Lin HJ, Tsai Y, Tsai CH and Tsai FJ (2009) A novel genetic variant of BMP2K contributes to high myopia. J Clin Lab Anal 23:362-367.

Masuda H, Tanaka K, Takagi M, Ohgami K, Sakamaki T, Shibata $\mathrm{N}$ and Takahashi K (1996) Molecular cloning and characterization of human non-smooth muscle calponin. J Biochem 120:415-424.

Ratcliffe KE, Tao Q, Yavuz B, Stoletov KV, Spring SC and Terman BI (2002) Sck is expressed in endothelial cells and 
participates in vascular endothelial growth factor-induced signaling. Oncogene 21:6307-6316.

Resta N, Giorda R, Bagnulo R, Beri S, Mina ED, Stella A, Piglionica M, Susca FC, Guanti G, Zuffardi O, et al. (2010) Breakpoint determination of 15 large deletions in PeutzJeghers subjects. Hum Genet 28:373-382.

Takehara-Kasamatsu Y, Tsuchida K, Nakatani M, Murakami T, Kurisaki A, Hashimoto O, Ohuchi H, Kurose H, Mori K, Kagami S, et al. (2007) Characterization of follistatinrelated gene as a negative regulatory factor for activin family members during mouse heart development. J Med Invest 54:276-288.

Traylor RN, Fan Z, Hudson B, Rosenfeld JA, Shaffer LG, Torchia BS and Ballif BC (2009) Microdeletion of 6q16.1 encompassing EPHA7 in a child with mild neurological abnormalities and dysmorphic features: Case report. Mol Cytogenet $2: 17$.

Tsuchida K, Arai KY, Kuramoto Y, Yamakawa N, Hasegawa Y and Sugino H (2000) Identification and characterization of a novel follistatin-like protein as a binding protein for the TGF-beta family. J Biol Chem 275:40788-40796.

Vannay A, Vasarhelyi B, Kornyei M, Treszl A, Kozma G, Gyorffy B, Tulassay T and Sulyok E (2006) Single-nucleotide polymorphisms of VEGF gene are associated with risk of congenital valvuloseptal heart defects. Am Heart J 151:878-881.

Volikos E, Robinson J, Aittomaki K, Mecklin JP, Jarvinen H, Westerman AM, de Rooji FW, Vogel T, Moeslein G, Launonen V, et al. (2006) LKB1 exonic and whole gene deletions are a common cause of Peutz-Jeghers syndrome. J Med Genet 43:e18.

Zhang J, Bahi N, Llovera M, Comella JX and Sanchis D (2009) Polypyrimidine tract binding proteins (PTB) regulate the expression of apoptotic genes and susceptibility to caspasedependent apoptosis in differentiating cardiomyocytes. Cell Death Differ 16:1460-1468.

Zhao W, Wang J, Shen J, Sun K, Zhu J, Yu T, Ji W, Chen Y, Fu Q and Li F (2010) Mutations in VEGFA are associated with congenital left ventricular outflow tract obstruction. Biochem Biophys Res Commun 396:483-488.

\section{Internet Resources}

DECIPHER, DatabasE of Chromosomal Imbalance and Phenotype in Humans using Ensemble Resources, http://decipher.sanger.ac.uk (June 30, 2011).

Associate Editor: Angela M. Vianna-Morgante

License information: This is an open-access article distributed under the terms of the Creative Commons Attribution License, which permits unrestricted use, distribution, and reproduction in any medium, provided the original work is properly cited. 